\title{
HUBUNGAN SOSIALISASI VISI MISI EFEKTIF TERHADAP TINGKAT IKATAN EMOSIONAL STAF DENGAN INSTITUSI DI PUSKESMAS PERAWATAN PLUS AWAAI KEC. SITOLU ORIKAB. NIAS UTARA
}

\author{
Crishartanto Simanungkalit, Irfan Setia Zega \\ Program Studi S-1 Keperawatan, STIKes Nauli Husada Sibolga \\ E-mail : crishartanto@yahoo.co.id \\ Program Studi S-1 Keperawatan, STIKes Nauli Husada Sibolga \\ E-mail : irfanzega1997@gmail.com
}

\begin{abstract}
Vision is a distant view of a health center or institution, vision can also be interpreted as the purpose of a health center or institution and what must be done to achieve these goals in the future or the future. This research is a quantitative study with a descriptive correlational design approach. This study aims to determine the relationship between the socialization of vision and effective mission towards the level of emotional bonding of staff with institutions in the Plus Awaai care clinic in 2019 by measuring the effective vision and mission socialization with the emotional level of all employees or employees working at the Plus Awaai care clinic. About the Pearson Correlation test to determine the relationship between the socialization vision and variables variables with the emotional level obtained from the Pearson Correlation test on the significant value is $0,000<0.05$ meaning that there is a relationship between the socialization of vision and mission with the emotional level. The degree of relationship is in strong correlation and is in positive relationship. Based on the results of the study can be put forward some suggestions as follows: 1) For Educational Institutions, this research should be useful for education, and it is recommended that the same research be carried out with a larger number of samples and in different places. 2). For Research Sites, In order to improve the provision of information on puskesmas profiles, activities that are often carried out at puskesmas, and routine activities carried out by puskesmas to socialize puskesmas vision and mission.
\end{abstract}

Keywords : Socialization of Vision and Mission, Emotional Level, Puskesmas

\begin{abstract}
Abstrak
Visi adalah pandangan jauh tentang suatu puskesmas ataupun lembaga, visi juga dapat di artikan sebagai tujuan puskesmas atau lembaga dan apa yang harus dilakukan untuk mencapai tujuannya tersebut pada masa yang akan datang atau masa depan. Penelitian ini merupakan penelitian kuantitatif dengan pendekatan desain Deskriptif Kolrelasi. Penelitian ini bertujuan untuk mengetahui Hubunga sosialisasi visi, misi efektif Terhadap tingkat ikatan emosional staf dengan institusi di puskesmas perawatan Plus Awaai Tahun 2019 dengan mengukur sosialisasi visi misi efektif dengan tingkatan emosional seluruh pegawai atau karyawan yang bekerja di puskesmas perawatan Plus Awaai. Tentang uji pearson corelation untuk mengetahui hubungan variabel sosialisasi visi misi dengan tingkat emosional diperoleh hasil dari uji pearson corelation terhadap nilai signifikan adalah $0,000<0,05$ artinya ada hubungan antara sosialisasi visi misi dengan tingkat emosional. Tingkat hubungan berada pada korelasi kuat dan berada pada hubungan positif. Berdasarkan hasil penelitian dapat dikemukakan beberapa saran sebagai berikut: 1) Bagi Institusi Pendidikan, Penelitian ini hendaknya berguna bagi pendidikan, dan disarankan dilakukan penelitian yang sama dengan jumlah sampel yang lebih besar dan di tempat yang berbeda. 2). Bagi Tempat Penelitian, Agar dapat meningkatkan pemberian informasi mengenai profil puskesmas, kegiatankegiatan yang sering dilakukan di puskesmas, dan adanya kegiatan rutin yang dilakukan puskesmas untuk mensosialisasikan visi misi puskesmas.
\end{abstract}

Kata Kunci : Sosialisasi Visi Misi, Tingkat Emosional, Puskesmas 


\section{PENDAHULUAN}

Visi adalah pandangan jauh tentang suatu puskesmas ataupun lembaga, visi juga dapat di artikan sebagai tujuan puskesmas atau lembaga dan apa yang harus dilakukan untuk mencapai tujuannya tersebut pada masa yang akan datang atau masa depan. Visi tidak dapat dituliskan secara lebih jelas karena menerangkan mengenai detail gambaran sistem yang di tujunya, ini disebabkan perubahan ilmu serta situasi yang sulit diprediksi selama masa yang panjang. Di bawah ini beberapa persyaratan yang hendaknya dipenuhi oleh suatu pernyataan Visi, diantaranya meliputi: 1 . Berorientasi ke depan. 2. Tidak dibuat berdasarkan kondisi pada saat ini. 3. Mengekspresikan kreatifitas. 4. Berdasar pada prinsip nilai-nilai yang mengandung penghargaan bagi masyarakat (Al-assaf, 2015).

Misi adalah suatu pernyataan tentang apa yang harus dikerjakan oleh perusahaan atau lembaga dalam usaha mewujudkan Visi tersebut. Misi perusahaan di artikan sebagai tujuan dan alasan mengapa perusahaan atau lembaga itu dibuat. Misi juga akan memberikan arah sekaligus batasan-batasan proses pencapaian tujuan. Ketika mendirikan sebuah puskesmas, organisasi, atau perusahaan, maka para pendiri biasanya akan menggagas impian atau tujuan yang ingin dicapai. Selain tujuan utama, biasanya mereka memiliki gagasan mengenai targettarget jangka pendek dan target jangka panjang. Untuk mewujudkan semua itu, perlu ada gagasan tertulis di dalam sebuah sistem manajemen.

Visi dan misi masuk dalam bentuk-bentuk gagasan atau pedoman tertulis tersebut (Aditama, 2015).

Sosialisasi yang efektif tercermin dari tingkat pemahaman untuk Visi, Misi, Tujuan dan Sasaran Puskesmas oleh seluruh pemangku kepentingan internal (internal stakeholders). Sosialisasi ini telah dijalankan sebaik mungkin karena mampu memberi pemahaman yang sangat baik kepada seluruh tenaga pekerja dan baik pegawai negeri maupun honorer. Sosialisasi dilakukan, baik kepada dokter, perawat, bidan, apotekes maupun tenaga kerja yang bekerja di puskesmas. Sosialisasi kepada pemangku kepentingan internal (internal stakeholders) dilakukan pada saat RAKER (rapat kerja). Sosialisasi kepada tenaga kerja dilakukan dengan pemasangan frame Visi, Misi, Tujuan dan Sasaran di ruang pertemuan (Dewi, 2014).

Sosialisasi kepada tenaga kerja dilakukan pada saat rapat staf yang pesertanya adalah pimpinan dan pejabat setingkat kepala puskesmas, sekretaris, kepala unit puskesmas dan pegawai lainnya yang dilaksanakan setiap sebulan sekali. Dari paparan di atas dan melihat banyaknya media sosialisasi jelas tergambar bahwa sosialisasi telah berjalan efektif, hal ini tercermin dari tingkat pemahaman untuk Visi, Misi, Tujuan dan Sasaran program studi oleh seluruh pemangku kepentingan internal (internal stakeholders), dan tenaga kerja, sehingga sosialisasi ini mampu memberi pemahamanan yang sangat baik kepada seluruh pegawai puskesmas. Visi dan Misi harus dituangkan dalam bentuk tulisan supaya seluruh pihak mengetahui apa yang menjadi tujuan dari sebuah puskesmas, organisasi, perusahaan, atau instansi tersebut. Ketika pembaca atau orang lain sudah tahu dan yakin akan langkah-langkah mencapai target utama. Maka kepercayaan pun bisa didapat (Gurley, 2015).

Pusat Kesehatan Masyarakat (Puskesmas) adalah salah satu sarana pelayanan kesehatan masyarakat yang amat penting di Indonesia. Puskesmas adalah unit pelaksana teknis dinas kabupaten/kota yang bertanggungjawab menyelenggarakan pembangunan kesehatan di suatau wilayah kerja (Depkes, 2011). Pengertian puskesmas adalah suatu unit pelaksana fungsional yang berfungsi sebagai pusat pembangunan kesehatan, pusat pembinaan peran serta masyarakat dalam bidang kesehatan serta pusat pelayanan kesehatan tingkat pertama yang menyelenggarakan kegiatannya secara menyeluruh, terpadu yang berkesinambungan pada suatu masyarakat yang bertempat tinggal dalarn suatu wilayah tertentu (Azrul Azwar, 1996). 
$\begin{array}{rrr}\text { Puskesmas } & \begin{array}{r}\text { merupakan } \\ \text { fungsional }\end{array} & \text { kesatuan } \\ \text { organisasi } & \text { yang }\end{array}$ menyelenggarakan upaya kesehatan yang bersifat menyeluruh, terpadu, merata dapat diterima dan terjangkau oleh masyarakat dengan peran serta aktif masyarakat dan menggunakan hasil pengembangan ilmu pengetahuan dan teknologi tepat guna, dengan biaya yang dapat dipikul oleh pemerintah dan masyarakat luas guna mencapai derajat kesehatan yang optimal, tanpa mengabaikan mutu pelayanan kepada perorangan (Depkes, 2009). Perwujudan masyarakat yang maju dan tercukupi kebutuhan lahiriah dan batiniahnya ditandai dengan meningkatnya kualitas hidup dan kehidupan masyarakat. Pencapaian kondisi sejahtera dalam arti masyarakat yang keadaan ekonomi, pendidikan dan kesehatan serta spiritualnya baik adalah dengan upaya peningkatan kreatifitas untuk mencapai keunggulan/prestasi sehingga dapat bertahan dan bersaing dalam berbagai bidang kehidupan, disamping upaya untuk mewujudkan keadilan.

Visi yang ingin dicapai melalui pembangunan kesehatan adalah masyarakat hidup dalam lingkungan yang sehat dengan perilaku hidup bersih dan sehat, memiliki kemampuan untuk menjangkau pelayanan kesehatan yang bermutu secara adil dan merata serta memiliki derajat kesehatan yang setinggi-tingginya. Lingkungan yang diharapkan adalah lingkungan yang kondusif untuk terwujudnya keadaan sehat yaitu lingkungan yang bebas dari polusi, tersedianya air bersih yang cukup, sanitasi lingkungan yang memadai, perumahan dan pemukiman yang sehat,perencanaan kawasan yang berwawasan kesehatan, serta terwujudnya kehidupan masyarakat yang saling tolong menolong dengan memelihara nilai-nilai budaya. Perilaku masyarakat yang diharapkan adalah yang bersifat proaktif untuk memelihara dan meningkatkan kesehatan, mencegah risiko terjadinya penyakit, melindungi diri dari ancaman penyakit, serta berpartisipasi aktif dalam gerakan kesehatan masyarakat (Ahanhanzo, 2016).
Kemampuan masyarakat untuk mendapatkan pelayanan kesehatan yang bermutu, diharapkan tercapai dengan mudah, karena pelayanan kesehatan diselenggarakan sesuai dengan standart dan etika profesi yang ada. Istilah emosi menurut Daniel Goleman (1995), seorang pakar kecerdasan emosional, yang diambil dari Oxford English Dictionary memaknai emosi sebagai setiap kegiatan atau pergolakan pikiran, perasaan, nafsu, setiap keadaan mental yang hebat dan meluap-luap. Lebih lanjut ia mengatakan bahwa emosi merujuk kepada suatu perasaan dan pikiranpikiran yang khas, suatu keadaan biologis dan psikologis, dan serangkaian kecendrungan untuk bertindak.

$$
\text { Penelitian Habsari (2014), }
$$

mengatakan adanya keterikatan antara visi, misi terhadap tingkat ikatan emosional dibuktikan dengan hasi penelitiannya dimana visi misi merupakan tolak ukur dari suatu kesuksesan puskesmas. Keterikatan visi misi puskesmas merupakan hasil dari komitmen bersama yang dilakukan oleh seluruh karyawan atau pegawai yang bekerja di suatu institusi guna mengeembangkan dan meningkatkan kualitas dari suatu puskesmas itu sendiri. Intinya, beberapa orang memiliki kecenderungan untuk memiliki emosi apa pun secara lebih intens atau memiliki intensitas afek (perbedaan individual dalam kekuatan di mana individu-individu mengalami emosi mereka).

Menurut Chaplin (1989) dalam Dictionary of psychology, emosi adalah sebagai suatu keadaan yang terangsang dari organisme mencakup perubahan-perubahan yang disadari, yang mendalam sifatnya dari perubahan perilaku. Chaplin (1989) membedakan emosi dengan perasaan, parasaan (feelings) adalah pengalaman disadari yang diaktifkan baik oleh perangsang eksternal maupun oleh bermacam-macam keadaan jasmaniah. Menurut Crow \& Crow (1958), emosi adalah "an emotion, is an affective experience that accompanies generalized inner adjustment and mental and physiological stirredup states in the individual, and that shows it self in his evert behaviour". Jadi, emosi adalah warna 
afektif yang kuat dan ditandai oleh perubahan-perubahan fisik.

Emosi adalah perasaan intens yang ditujukan kepada seseorang atau sesuatu. Emosi adalah reaksi terhadap seseorang atau kejadian. Emosi dapat ditunjukkan ketika merasa senang mengenai sesuatu, marah kepada seseorang, ataupun takut terhadap sesuatu. Kata "emosi" diturunkan dari kata bahasa Prancis, émotion, dari émouvoir, 'kegembiraan' dari bahasa Latin emovere, dari e- (varian eks-) 'luar' dan movere 'bergerak'. Kebanyakan ahli yakin bahwa emosi lebih cepat berlalu daripada suasana hati. Sebagai contoh, bila seseorang bersikap kasar, manusia akan merasa marah. Perasaan intens kemarahan tersebut mungkin datang dan pergi dengan cukup cepat tetapi ketika sedang dalam suasana hati yang buruk, seseorang dapat merasa tidak enak untuk beberapa jam (Sudrajat, 2015).

Angka kejadian yang terjadi di puskesmas di Indonesia banwa dari 1.661 Puskesmas daerah terpencil, perbatasan, dan kepulauan di 361 kabupaten/kota di 29 Provinsi. Semua rata-rata sudah memiliki visi, misi tetapi tidak terlaksananya secara baik dan terukur. Visi misi hanya sebagai pelengkap dalam profil puskesmas. Harapan dari pemerintah dan puskesmas yang akan datang dimana setiap puskesmas harus mensosialisasikan visi, misi puskesmas kepada seluruh elemen yang bekerja di puskesmas tersebut. Terciptanya sebuah sosialisasi visi, misi tentulah berdampak baik kepada puskesmas dimana puskesmas memiliki arah yang jelas, mau dibawa kemana nanti mutu peayanan puskesmas (Data Puskesmas RI, 2018).

Puskesmas yang ada di sumatera utara yang berjumlah 581 puskesmas yang terdiri dari 406 non rawat inap dan 175 rawat inap mayoritas sudah memiliki visi, misi. Visi, misi setiap puskesmas adalah berbedabena dimana setiap puskesmas diberi kesempatan untuk mengembangkan puskesmas masing-masing setiap daerah. Perumusan visi, misi didasarkan pada komitmen bersama sesama pekerja yang ada dipuskesmas. Landasan perumusan visi, misi haruslah sesuai fungsi puskesmas itu sendiri dan dapat dicapat dalam waktu tertentu. Kejadian yang ditemukan di kebanyakan puskesmas masih banyak puskesmas yang tidak melakukan sosialisasi visi, misi puskesmas sehingga menghambat dalam pemberian pelayanan yang bermutu bagi masyarakat (Data Puskesmas Sumatera Utara, 2018).

UPT Puskesmas Perawatan Plus Awa'ai terletak Provinsi Sumatera Utara di wilayah Kabupaten Nias Utara Kecamatan Sitolu Ori , Kurang Lebih Berjarak 20 km dari Ibu Kota Kabupaten Nias Utara. Luas Wilayah Kerja Puskesmas Perawatan Plus Awa'ai 78,81 Km2 terdiri dari 6 (Enam) Desa yaitu : Desa Hilimbosi, Desa Umbubalodano, Desa Tetehosi Maziaya, Desa Hilisalo'o, Desa Fulolo Salo’o, Desa Botombawo. Dengan Batas Wilayah, Sebelah timur : Berbatasan dengan Kota Gunungsitoli, Sebelah Barat: Berbatasan dengan Kecamatan Lotu, Sebelah utara : Berbatasan dengan Kecamatan Tuhemberua, Sebelah Selatan: Berbatasan dengan Kecamatan Namohalu Esiwa. Wilayah kerja Puskesmas Perawatan Plus Awa'ai terjauh adalah kampung Sanawuyu, Desa Umbubalodano kurang lebih $15 \mathrm{Km} 2$ dari Puskesmas Perawatan Plus Awa'ai yang mana sebagian jalannya harus ditempuh dengan jalan kaki dan desa terdekat adalah Desa Hilimbosi (Profi Puskesmas Perawatan Plus Awa'ai, 2018) .

Berdasarkan survey awal yang dilakukan peneliti terhadap pekerja di puskesmas perawatan plus Awaai Kec. Sitolu Ori, Kab. Nias Utara, 1. Dari 17 orang perawat mengatakan bahwa sosialisasi visi, misi pernah sekali dilakukan dan tidak secara rutin sehingga tindak lanjutnya tidak ada. 2 . Dari 19 bidan mengatakan bahwa sosialisasi visi misi tidaklah penting dalam tujuan pencapaian mutu pelayanan puskesmas. 3 . Dari 3 orang farmasi mengatakan bahwa sosialisasi visi misi hanyalah bahan pelengkap dalam melengkapi profil puskesmas. 4. Dari 2 orang sarjana kesehatan masyarakat mengatakan bahwa sosialisasi visi misi hanyalah sebagai mimpi 
puskesmas dan tidak pernah serius untuk dijalankan. 5. Dari 2 orang sopir dan penjaga mengatakan bahwa sosialisasi visi misi tidak pernah didengar apalagi untuk menerapkannya, dan mengatakan hanya sebatas kerja di puskesmas ini. Berdasarkan latar belakang di atas, penulis tertarik untuk mengetahui pengaruh Hubungan sosialisasi visi misi efektif terhadap tingkat ikatan emosional staf dengan institusi di puskesmas perawatan plus Awaai Kec. Sitolu Ori, Kab. Nias Utara Tahun 2019.

\section{METODE PENELITIAN}

Penelitian ini merupakan penelitian kuantitatif dengan pendekatan desain Deskriptif Korelasi. Penelitian ini bertujuan untuk mengetahui Hubungan sosialisasi visi, misi efektif Terhadap tingkat ikatan emosional staf dengan institusi di puskesmas perawatan Plus Awaai Tahun 2019 dengan mengukur sosialisasi visi misi efektif dengan tingkatan emosional seluruh pegawai atau karyawan yang bekerja di puskesmas perawatan Plus Awaai.

\section{Lokasi dan Waktu Penelitian}

Lokasi penelitian ini berada di Puskesmas Perawatan Pus Awaai Kec. Sitolu Ori, Kab. Nias utara, terdapat sekitar 76 orang yang bekerja di di puskesmas perawatan Plus Awaai. Setting penelitian adalah tempat dan kondisi atau keadaan dimana studi penelitian yang sebenarnya berlangsung (Polit \& Beck, 2012). Pemilihan lokasi didasarkan pada pertimbangan belum pernah dilakukan penelitian sejenis dan ditentukan masalah sosialisasi visi, misi efektif Terhadap tingkat ikatan emosional staf dengan institusi di puskesmas. Waktu penelitian dilakukan pada tahun 2019.

\section{Populasi dan Sampel}

Populasi dalam penelitian ini adalah seluruh pegawai atau karyawan yang berjumlah 76 orang di puskesmas perawatan Plus Awaai. Sampel adalah bagian dari jumlah dan karakteristik populasi yang dimiliki oleh populasi (Sugiyono, 2011). Berdasarkan tabel penentuan jumlah sampel menurut Sugiyono (2011), jumlah sampel didalam penelitian ini berjumlah 43 orang yang didapat dengan menggunakan rumus Notoatmodjo ( 2005 ) yaitu $\mathrm{n}=\mathrm{N} / 1+\mathrm{N}\left(\mathrm{d}^{2}\right)$, dengan tingkat kepercayaan atau ketepatan yang diinginkan $(0,1 \%)$ dan pengambilan sampel dilakukan secara acak sederhana.

\section{HASIL PENELITIAN \\ Karakteristik Responden}

Berdasarkan hasil penelitian, karakteristik responden berdasarkan umur, jenis kelamin, status pekerjaan, pendidikan terakhir dan lama bekerja, dapat dilihat pada tabel dibawah ini.

Tabel 1. Distribusi Responden Berdasarkan Karakteristik Responden Di Puskesmas Perawatan Plus Awaai Kec. Sitolu Ori, Kab. Nias Utara $(\mathrm{N}=43)$.

\begin{tabular}{|c|c|c|c|}
\hline No & $\begin{array}{l}\text { Aspek Yang } \\
\text { Dinilai }\end{array}$ & Jumlah & $\begin{array}{c}\text { Persentase } \\
(\%)\end{array}$ \\
\hline \multirow[t]{5}{*}{1.} & Umur & & \\
\hline & 23-33 tahun & 23 & 53,3 \\
\hline & 34-49 tahun & 17 & 17 \\
\hline & 50-58 tahun & 3 & 7 \\
\hline & Jumlah & 43 & 100 \\
\hline \multirow[t]{4}{*}{2.} & Jenis Kelamin & & \\
\hline & Laki-laki & 10 & 23,3 \\
\hline & Perempuan & 33 & 76,7 \\
\hline & Jumlah & 43 & 100 \\
\hline \multirow[t]{4}{*}{3.} & Pekerjaan & & \\
\hline & Non PNS & 11 & 25,6 \\
\hline & PNS & 32 & 74,4 \\
\hline & Jumlah & 43 & 100 \\
\hline \multirow[t]{5}{*}{4.} & Pendidikan & & \\
\hline & Terakhir & & \\
\hline & SMP & 8 & 18,6 \\
\hline & SMA/SPK & 11 & 25,6 \\
\hline & D-III/ S1 & 24 & 55,8 \\
\hline \multirow[t]{8}{*}{5.} & Lama & & \\
\hline & Bekerja & & \\
\hline & 1-5 tahun & 20 & 46,5 \\
\hline & 6-10 tahun & 12 & 27,9 \\
\hline & 11-15 tahun & 6 & 14,0 \\
\hline & 16-20 tahun & 2 & 4,7 \\
\hline & $>20$ tahun & 3 & 7,0 \\
\hline & Jumlah & 43 & 100 \\
\hline
\end{tabular}

Tabel 1. menunjukkan bahwa dari 43 pegawai yang bekerja di Puskesmas Perawatan Plus Awaai Kec. Sitolu Ori, Kab. Nias Utara berdasarkan umur mayoritas 
berusia 23-33 tahun sebanyak 23 orang $(53,5 \%)$, berdasarkan jenis kelamin mayoritas berjenis kelamin perempuan sebanyak 33 orang $(76,7 \%)$, berdasarkan status pekerjaan mayoritas PNS sebanyak 32 orang $(74,4 \%)$, berdasarkan pendidikan terakhir mayoritas berpendidikan D-III/S1 sebanyak 24 orang $(55,8 \%)$. berdasarkan lama bekerja mayoritas 1-5 tahun sebanyak 20 orang $(46,5 \%)$

\section{Distribusi Frekuensi Sosialisasi Visi Misi}

Hasil penelitian distribusi frekuensi berdasarkan Visi Misi yang diteliti adalah sebagai berikut:

Tabel 2. Distribusi Frekuensi Sosialisai Visi Misi Puskesmas Perawatan Plus Awaai Kab. Nias Utara 2019, $(\mathrm{n}=43)$.

\begin{tabular}{lcc}
\hline $\begin{array}{c}\text { Sosialisasi Visi } \\
\text { Misi }\end{array}$ & Jumlah & Persen \\
\hline Baik & 18 & 41,9 \\
Cukup & 7 & 16,3 \\
Buruk & 18 & 41,9 \\
\hline Total & 43 & 100 \\
\hline
\end{tabular}

Tabel 2. menunjukkan bahwa dari 43 responden yang diteliti terdapat 24 responden mayoritas menyatakan Sosialisasi Visi Misi adalah baik yaitu sebanyak 18 orang $(41,9 \%)$ dan minoritas Sosialisasi Visi Misi adalah cukup 7 orang $(16,3 \%)$.

\section{Distribusi Frekuensi Ikatan Emosional}

Hasil penelitian distribusi frekuensi berdasarkan Ikatan Emosional yang diteliti adalah sebagai berikut:

Tabel 3. Distribusi Frekuensi Tingkat Emosional Puskesmas Perawatan Plus Awaai Kab. Nias Utara 2019, $(n=43)$.

\begin{tabular}{lcc}
$\begin{array}{l}\text { Tingkat } \\
\text { Emosional } \\
\text { Puskesmas }\end{array}$ & Jumlah & $\begin{array}{c}\text { Persen } \\
(\boldsymbol{\%})\end{array}$ \\
\hline Baik & & \\
Cukup & 20 & 56,5 \\
Buruk & 16 & 16,3 \\
\hline Total & 7 & 37,2 \\
\hline
\end{tabular}

Tabel 3. menunjukkan bahwa 43 responden mayoritas menyatakan tingkat emosional staf baik yaitu 22 orang $(56,5 \%)$ dan minoritas tingkat emosional staf buruk yaitu sebanyak 7 orang $(37,2 \%)$.

\section{Analisis Bivariat}

Di bawah ini akan ditampilkan hasil uji statistik untuk hubungan sosialisasi visi misi dengan tingkat emosional di Puskesmas Awaai Kec. Sitolu Ori Kab. Nias Utara Tabel 4. Korelasi Variabel Visi Misi dengan Tingkat Emosional di Puskesmas Perawatan Plus Awaai Kab. Nias Utara Utara 2019, $(\mathrm{n}=43)$

\begin{tabular}{|c|c|c|c|}
\hline \multicolumn{4}{|c|}{ Correlations } \\
\hline & & $\begin{array}{c}\text { Sosialisasi_- } \\
\text { Visi_Misi }\end{array}$ & $\begin{array}{c}\text { Tingkat_ } \\
\text { Emosion } \\
\text { al } \\
\end{array}$ \\
\hline \multirow{4}{*}{$\begin{array}{l}\text { Sosialis } \\
\text { asi_Visi } \\
\text { _Misi }\end{array}$} & Pearson & 1 & $.956^{* *}$ \\
\hline & Correlation & & \\
\hline & Sig. (2-tailed) & & .000 \\
\hline & $\mathrm{N}$ & 43 & 43 \\
\hline \multirow{4}{*}{$\begin{array}{l}\text { Tingkat } \\
\text { _Emosi } \\
\text { onal }\end{array}$} & Pearson & $.956^{* *}$ & 1 \\
\hline & Correlation & & \\
\hline & Sig. (2-tailed) & .000 & \\
\hline & $\mathrm{N}$ & 43 & 43 \\
\hline $\begin{array}{l}\text { **. Corr } \\
\text { tailed). }\end{array}$ & ation is signi & nt at the 0.0 & level (2- \\
\hline
\end{tabular}

Tabel 4. tentang uji pearson corelation untuk mengetahui hubungan variabel sosialisasi visi misi dengan tingkat emosional diperoleh hasil dari uji pearson corelation terhadap nilai signifikan adalah $0,000<0,05$ artinya ada hubungan antara sosialisasi visi misi dengan tingkat emosional. Tingkat hubungan berada pada korelasi kuat dan berada pada hubungan positif.

\section{PEMBAHASAN}

\section{Karakteristik Responden}

Visi pembangunan kesehatan yang diselenggarakan oleh puskesmas adalah tercapainya Kecamatan Sehat menuju terwujudnya Indonesia Sehat. Kecamatan Sehat adalah gambaran masyarakat kecamatan masa depan yang ingin dicapai melalui pembangunan kesehatan, yakni masyarakat yang hidup dalam lingkungan dan dengan perilaku sehat, memiliki kemampuan untuk menjangkau pelayanan kesehatan yang bermutu secara adil dan 
merata, serta memiliki derajat kesehatan yang setinggi-tingginya. Umur responden pada penelitian ini menunjukkan bahwa dari 43 pegawai yang bekerja di Puskesmas Perawatan Plus Awaai Kec. Sitolu Ori, Kab. Nias Utara berdasarkan umur mayoritas berusia 23-33 tahun sebanyak 23 orang $(53,5 \%)$, dan minoritas berumur 50-58 tahun.

Faktor usia terkait dengan kejadian perilaku yaitu terjadinya beberapa perubahan fisiologis. Selain itu, usia 23-33 tahun, merupakan usia produktif dalam bekerja. Hasil penelitian yang dilakukan Chaningsih (2018) di Fakultas UGM (universitas Gajah Mada) didapat hasil bahwa angka usia produktif berada di kisaran umur 23-40 tahun. Pegawai atau staf yang bekerja di Puskesmas Pelawatan Plus Awaai Kab. Nias Utara masih didominasi oleh tenaga muda terbukti dari hasil penelitian yang telah dilakukan di puskesmas tersebut. Menurut asumsi penulis pada usia 23-33 tahun merupakan usia keemasan dimana setiap pegawai atau staf merupakan awal dari untuk membengun sebuah karir dan menggali semua potensi yang ada dalam diri.

\section{Jenis Kelamin Responden}

Jumlah wanita umumnya lebih banyak dari jumlah laki-laki, terbukti dari survey yang dilakukan oleh WHO pada tahun 2016 jumlah penduduk wanita lebih banyak dari laki-laki dengan perbandingan 1 banding $3(1: 3)$. \%). Berdasarkan jenis kelc mayoritas berjenis kelamin perem 1 sebanyak 33 orang $(76,7 \%)$, dan minoritas laki-laki sebanyak 10 orang $(23,3 \%)$. Secara tersirat memang penelitian ini sesuai dengan teori yang ada. Tetapi, apabila ditelaah lebih lanjut, maka dapat diketahui bahwa wanita sebagian responden perempuan dalam penelitian ini telah masuk pada pekerjaan yang tidak memerlukan tenaga kuat, seperti kebanyakan yang dilakukan oleh laki-laki contohnya mengangkat beban berat pada saat bekerja. (Kumar, et al., 2018).

Pekerjaan di bidang kesehatan selalu didominasi oleh kaum wanita karena pekerjaan ini merupakan pekerjaan yang memerlukan kesabaran dan pengabdian kepada masyarakat. Menurut asumsi peneliti karena pekerjaan di puskesmas dilakukan oleh kaum perempuan disebabkan oleh adanya hasrat dari dalam diri seorang perempuan untuk merawat pasien, mengobati dan melayani pasien terbukti dari kegiatan yang dilakukan oleh perempuan kebanyakan di rumah merawat anak atau keluarga dalam menjalankan perannya sebagai ibu rumah tangga yang tugasnya menjaga anak-anak dirumah.

\section{Pendidikan Responden}

Faktor yang mempengaruhi prilaku adalah pendidikan. Dari tabel diatas responden pada penelitian ini menunjukkan bahwa sebagian besar dari mereka mempunyai latar belakang pendidikan Berdasarkan Pendidikan Terakhir, mayoritas responden berpendidikan D-III/S1 sebanyak 24 orang $(55,8 \%)$. minoritas berpendidikan DIII, yaitu 2 orang (13\%) dan minoritas berpendidikan SMP yaitu sebanyak 8 orang $(18,6 \%)$. Menurut A Wawan dan Dewi M bahwa pendidikan semakin tinggi maka akan semakin banyak pengetahuan yang dimiliki tentang visi misi puskesmas. Responden pada penelitian ini menunjukkan sebagian besar lulusan perguruan tinggi harunya sudah semua orang atau responden untuk mengetahui sosialisasi visi misi puskesmas yang baik dan yang benar.

Tingkat pendidikan responden berhubungan sosialisasi visi misi dengan ikatan emosional fenomena ini karena pendidikan yang tinggi tidak mempengaruhi kebiasaan mensosialisasi visi misi puskesmas. Hal ini dapat dilihat dari jumlah responden yang berpendidikan tinggi tetapi $55,8 \%$ hasil uji hasil uji yang didapat, masih terdapat responden yang belum mengetahui selusuhnya tentang visi misi puskesmas. Tetapi teori Green menyatakan bahwa pendidikan terbasuk faktor predisposisi dalam perubahan perilaku seseorang. Pengetahuan mengenai kesehatan yang dimiliki oleh responden dapat kualitas mutu dalam menjalankan visi misi puskesmas. Berdasarkan uraian di atas dapat dikemukakan bahwa ada ketidak sesuaian 
antara teori dan hasil penelitian yang diperoleh merupakan kelemahan penelitian selanjutnya.

\section{Sosialisasi Visi Misi Puskesmas}

Kecamatan Sehat adalah gambaran masyarakat kecamatan masa depan yang ingin dicapai melalui pembangunan kesehatan, yakni masyarakat yang hidup dalam lingkungan dan dengan perilaku sehat, memiliki kemampuan untuk menjangkau pelayanan kesehatan yang bermutu secara adil dan merata, serta memiliki derajat kesehatan yang setinggi-tingginya. Indikator Kecamatan Sehat yang ingin dicapai mencakup 4 indikator utama yakni (1) lingkungan sehat, (2) prilaku sehat, (3) cakupan pelayanan kesehatan yang bermutu serta (4) derajat kesehatan penduduk kecamatan.

Hasil dari penelitian dari sosialisasi visi misi didapat hasil bahwa dari 24 responden mayoritas menyatakan Sosialisasi Visi Misi adalah baik yaitu sebanyak 18 orang $(41,9 \%)$ dan minoritas Sosialisasi Visi Misi adalah cukup 7 orang (16,3\%). Hasil penelitian lain menyebutkan sosialisasi visi misi pada puskesmas di Desa Caturtunggal sebagian besar (65\%) termasuk dalam kategori sedang, hal ini sesuai dengan latar belakang pendidikan responden yang sebagian besar $(55,8 \%)$ berpendidikan DIII/S-1 ataupun sudah menempuh perguruan tinggi yang sudah memiliki banyak pengetahuan. Untuk meningkatkan kualitas pelayanan yang diberikan kepada masyarakat adanya peneningkatan pengetahuan melalui pemberian pelatihan dan praktik lapangan dengan cara berkesinambungan dalam mensosialisasikan visi misi yang ada di puskesmas Perawatan Plus Awaai Kec. Sitolu Ori Kab. Nias Utara.

\section{Tingkat Emosional}

Orang yang mendapatkan ikatan (Attachment) yang cukup, akan merasa dirinya aman (Secure) dan lebih positif terhadap kelompoknya, menunjukkan ketertarikan yang lebih besar terhadap orang lain di dalam mengajak bekerja. Berarti, ini bersifat sosial, tetapi juga pada orang lain. Sebaliknya yang memiliki ikatan yang tidak aman/kuat (Insecure) akan takut pada orang asing dan akan merasa sedih jika berpisah dengan tempat pekerjaanya. Dari hasil tingkat emosional staf dengan institusi bahwa 43 responden mayoritas menyatakan tingkat emosional staf baik yaitu 22 orang $(56,5 \%)$ dan minoritas tingkat emosional staf buruk yaitu sebanyak 7 orang $(37,2 \%)$ yang disebabkan karen di puskesmas perawatan pus awaai telah diterapkan budaya saling tolong menolong antara satu dengan yang lainnya.

Semua jenis emosi, kebahagiaan adalah emosi yang paling diinginkan dan dicari oleh semua orang. Emosi ini diartikan sebagai keadaan emosi yang menyenangkan, seperti perasaan puas, gembira, dan sejahtera. Kebahagiaan dapat diekspresikan dengan banyak cara, seperti melalui: 1). Ekspresi wajah tersenyum, 2). Nada suara ceria yang menyenangkan dan 3). Bahasa tubuh yang terlihat santai atau bersemangat. Perasaan bahagia mengarahkan seseorang untuk bersyukur serta memahami diri sendiri dan orang lain lebih baik lagi. Kebahagiaan merupakan salah satu contoh emosi positif yang memainkan peran penting dalam kesehatan fisik dan mental. Salah satunya adalah memperpanjang usia. Sebaliknya, jika Anda tidak merasa bahagia, seperti kecemasan, stres, depresi, dan kesepian dapat berdampak buruk bagi kesehatan dan menurunkan tingkat kualitas hidup.

Menurut Asumsi Penulis Tingkat Emosional dipengaruhi oleh situasi saat bekerja dan berapa penghasilan yang didapat perbulannya, kita tau penghasilan PNS sudah diatur sedemikian rupa yaitu sesuai pangkat dan golongan. Penerapan sistem penggajian di PNS telah diatur oleh pemerintah dan telah disesuaikan dengan kebutuhan di kehidupan sehari-harin dan besarnya diatas rata-rata UMR (upah minimum regional) dan akan betah dalam bekerja sampai memperoleh masa pensiun. 


\section{Hubungan Korelasi Antara Sosialisasi Visi Misi Dengan Tingkat Emosional Di Puskesmas Perawatan Awaai Kec. Sitolu Ori Kab. Nias Utara}

Berdasarkan Korelasi antara sosialisasi visi misi dengan tingkat emosional diperoleh hasil dari uji pearson corelation terhadap nilai signifikan adalah $0,000<0,05$ artinya ada hubungan antara sosialisasi visi misi dengan tingkat emosional. Tingkat hubungan berada pada korelasi kuat dan berada pada hubungan positif. Hasil dari penelitian Chaplin (1989) dalam Dictionary of psychology, emosi adalah sebagai suatu keadaan yang terangsang dari organisme mencakup perubahan-perubahan yang disadari, yang mendalam sifatnya dari perubahan perilaku. Chaplin (1989) membedakan emosi dengan perasaan, parasaan (feelings) adalah pengalaman disadari yang diaktifkan baik oleh perangsang eksternal maupun oleh bermacam-macam keadaan jasmaniah. Menurut Crow \& Crow (1958), emosi adalah "an emotion, is an affective experience that accompanies generalized inner adjustment and mental and physiological stirredup states in the individual, and that shows it self in his evert behaviour". Jadi, emosi adalah warna afektif yang kuat dan ditandai oleh perubahan-perubahan fisik.

Emosi adalah perasaan intens yang ditujukan kepada seseorang atau sesuatu. Emosi adalah reaksi terhadap seseorang atau kejadian. Emosi dapat ditunjukkan ketika merasa senang mengenai sesuatu, marah kepada seseorang, ataupun takut terhadap sesuatu. Kata "emosi" diturunkan dari kata bahasa Prancis, émotion, dari émouvoir, 'kegembiraan' dari bahasa Latin emovere, dari e- (varian eks-) 'luar' dan movere 'bergerak'. Kebanyakan ahli yakin bahwa emosi lebih cepat berlalu daripada suasana hati. Sebagai contoh, bila seseorang bersikap kasar, manusia akan merasa marah. Perasaan intens kemarahan tersebut mungkin datang dan pergi dengan cukup cepat tetapi ketika sedang dalam suasana hati yang buruk, seseorang dapat merasa tidak enak untuk beberapa jam (Sudrajat, 2015).
Dari paparan di atas dan melihat banyaknya media sosialisasi jelas tergambar bahwa sosialisasi telah berjalan efektif, hal ini tercermin dari tingkat pemahaman untuk Visi, Misi, Tujuan dan Sasaran program studi oleh seluruh pemangku kepentingan internal (internal stakeholders), dan tenaga kerja, sehingga sosialisasi ini mampu memberi pemahamanan yang sangat baik kepada seluruh pegawai puskesmas. Emosional didasarkan pada perasaan atau sikap seseorang dalam bereaksi pada suatu kondisi. Emosional adalah suatu perasaan dan pikiran yang khas, suatu keadaan biologis, psikologis dan serangkaian kecenderungan untuk bertindak Pada suatu perubahan sangat dibutuhkan yang namanya faktor Emosional terhadap sistem pelayanan. Sistem pelayanan yang bersifat emosional, dimana mereka lebih mengedepankan aspek religius atau rohani seperti begitu sukarela menggunakan tenaga dalam memberikan pelayanan yang terbaik bagi masyarakat.

Sejumlah

Teoretikus mengelompokkan emosi dalam golongangolongan besar, Beberapa anggota golongan tersebut adalah sebagai berikut: 1.) Amarah: beringas, mengamuk, benci, marah besar, jengkel, kesal hati, terganggu, rasa pahit, berang, tersinggung, bermusuhan, dan barang kali yang paling hebat, tindak kekerasan dan kebencian yang patologis. 2). Kesedihan: pedih, sedih, muram, suram, melankolis, mengasihani diri, kesepian, ditolak, putus asa, dan kalau menjadi patologis; depresi berat. 3) Rasa takut: cemas, takut, gugup, khawatir, waswas, perasaan takut sekali, waspada, sedih, tidak tenang, ngeri, kecut; sebagai patologi, fobia dan panic, dan 4) Kenikmatan: bahagia gembira, riang, puas, ringan, senang, terhibur, bangga, kenikmatan indrawi, takjub, rasa terpesona, rasa puas, rasa terpenuhi, kegirangan luar biasa, senang, senang sekali, dan batas ujungnya; mania.

\section{KESIMPULAN}

Kesimpulan hasil penelitian ini adalah :

1. Berdasarkan karakteristik responden berdasarkan umur mayoritas berusia 23-33 tahun sebanyak 23 orang $(53,5 \%)$, 
berdasarkan jenis kelamin mayoritas berjenis kelamin perempuan sebanyak 33 orang $(76,7 \%)$, berdasarkan status pekerjaan mayoritas PNS sebanyak 32 orang $(74,4 \%)$, berdasarkan pendidikan terakhir mayoritas berpendidikan D-III/S1 sebanyak 24 orang $(55,8 \%)$. berdasarkan lama bekerja mayoritas 1-5 tahun sebanyak 20 orang $(46,5 \%)$.

2. Berdasarkan sosialisasi visi misi menunjukkan bahwa dari 43 responden terdapat24 responden mayoritas menyatakan Sosialisasi Visi Misi adalah baik yaitu sebanyak 18 orang $(41,9 \%)$ dan minoritas Sosialisasi Visi Misi adalah cukup 7 orang $(16,3 \%)$.

3. Berdasarkan tingkat emosiona1 menunjukkan bahwa dari 43 responden mayoritas menyatakan tingkat emosional staf baik yaitu 22 orang $(56,5 \%)$ dan minoritas tingkat emosional staf buruk yaitu sebanyak 7 orang $(37,2 \%)$.

4. Berdasarkan Korelasi uji pearson corelation untuk mengetahui hubungan variabel sosialisasi visi misi dengan tingkat emosional diperoleh hasil dari uji pearson corelation terhadap nilai signifikan adalah $0,000<0,05$ artinya ada hubungan antara sosialisasi visi $n$ '. dengan tingkat emosional. Ting 53 hubungan berada pada korelasi kuat cauı berada pada hubungan positif.

\section{SARAN}

1. Bagi Institusi Pendidikan

Penelitian ini hendaknya berguna bagi pendidikan, dan disarankan dilakukan penelitian yang sama dengan jumlah sampel yang lebih besar dan di tempat yang berbeda.

2. Bagi Tempat Penelitian

Agar dapat meningkatkan pemberian informasi mengenai profil puskesmas, kegiatan-kegiatan yang sering dilakukan di puskesmas, dan adanya kegiatan rutin yang dilakukan puskesmas untuk mensosialisasikan visi misi puskesmas.

3. Bagi Responden

Diharapkan bagi responden agar menerapkan perilaku yang baik dan benar dalam menjalankan visi misi yang telah disepakati bersama untuk kemajuan pelayananan puskesmas.

\section{REFERENSI}

Abdul Nasir, (2017). Komunikasi Massa Dalam Keperawatan: Teori dan Aplikasi. Jakarta: Salemba Medika.

Ahanhanzo, J., Odushin, D.E \& BibiAdelakoun, A. (2016). Building a Vision for Education in Benin. Prospects, 36(1), 9-21.

Ancok, D. (2014). Revitalisasi Sumber Daya Manusia dalam Era Perubahan. Kelola: Gadjah Mada University Business Review (8), 104-117.

Aditama, C. Y. (2015). Manajemen Administrasi Rumah Sakit. (Edisi 2). Jakarta: UI Press.

Al-assaf, A. F. (2015). Mutu Pelayaan Kesehatan: Perspektif Internasional. Jakarta: EGC.

Bainbridge, S. (2017). Creating A Vision for Your School, Moving from Purpose to Practice. London: Paul Chapman Publishing, A SAGE Publications Company.

Dewi, Y.R. (2014). Pemahaman Karyawan Terhadap Visi, Misi Dan Tujuan FIKOM UPDM. Wacana, 13(3), 246-255

Gurley, D.K., Peters, G.B., Collins, L. Fifolt, M. (2015). Mission, Vision, Values, and Goals: An Exploration of Key Organizational Statements And Daily Practice In Schools. J Educ Change, 16, 217.

Nursalam. (2008). Konsep dan Penerapan Metodologi Penelitian Ilmu Keperawatan: Pedoman Skripsi, Tesis, dan Instrumen. Edisi 2. Jakarta: Salemba Medika.

Polit. DE \& Hungler, BP. (1999). Nursing Research. Principles and Methods. 6 Ed.

Philadelphia: JB Lippincott.

Sastroasmoro S. \& Ismail S. 1995. DasarDasar Metodologi Penelitian Klinis. Jakarta: Binarupa Aksara. 
Sugiyono, (2005). Komunikasi Terapeutik: Teori dan Praktik. Jakarta: EGC

Shives, (1994). Teknik Komunikasi Terapeutik. Philadelphia: JB Lippincott.

Riduwan. (2012). Skala Pengukuran Variabel-Variabel Penelitian. Bandung: Alfabeta.

Sudrajat, S. (2015). Dasar-Dasar Penelitian Ilmiah. Bandung: Pustaka Setia.

Sukaningtyas, D., Satori, D., \& Sa'ud, U.S. (2017). Pengembangan Kapasitas Manajemen Sekolah Dalam Membangun Pemahaman Visi dan
Misi. Cakrawala Pendidikan, $36(2), \quad 257-266$.

Sukmadinata, N.S. (2013). Metode Penelitian Pendidikan. Bandung : PT Remaja Rosdakarya.

Sunardi, D. \& Sudarwati, W. (2014). Pengukuran Tingkat Pemahaman Civitas Akademika Terhadap Visi Misi Jurusan Teknik Industri. Jurnal Integrasi Sistem Industri UMJ, 1(2), 1-12.

Wibisono, D. (2016). Manajemen Kinerja, Konsep, Desain, dan Teknik Perusahaan. Jakarta: Erlangga 